RASĀYAN J. Chem.

Vol. 13 | No. 1 |514 - 520| January - March | 2020 ISSN: 0974-1496 | e-ISSN: 0976-0083 | CODEN: RJCABP http://www.rasayanjournal.com http://www.rasayanjournal.co.in

\title{
EFFECTS OF PYROLYSIS TEMPERATURE ON THE COMPOSITION OF LIQUID SMOKE DERIVED FROM OIL PALM EMPTY FRUIT BUNCHES
}

\author{
M. Faisal*, Asri Gani, Farid Mulana, Hera Desvita and S. Kamaruzzaman \\ Department of Chemical Engineering, Syiah Kuala University, Banda Aceh, 23111, Indonesia \\ *E-mail:mfaisal@unsyiah.ac.id
}

\begin{abstract}
Oil palm empty fruit bunches (OPEFB) contain cellulose, hemicellulose, and lignin that can be pyrolyzed to produce liquid smoke. This study characterizes the composition of liquid smoke compounds from OPEFB pyrolyzed at various temperatures. OPEFB pyrolysis was performed using slow-reactor pyrolysis at temperatures of $300^{\circ} \mathrm{C}$, $320^{\circ} \mathrm{C}, 340^{\circ} \mathrm{C}, 380^{\circ} \mathrm{C}$, and $420^{\circ} \mathrm{C}$. The composition of the chemical compounds in the liquid smoke was then analyzed using gas chromatography-mass spectrometry (GC-MS), and the concentrations of phenol and acetic acid were analyzed using spectrophotometry and high-performance liquid chromatography (HPLC), respectively. The results show that pyrolysis temperature affects the composition of liquid smoke compounds. The GC-MS analysis shows that liquid smoke contains more than 15 chemical compounds, including acetic acid, pyridine, benzene, benzenesulfonic acid, phenol, and toluene. Acetic acid and phenol dominate the composition of the liquid smoke. The HPLC analysis shows that the concentration of acetic acid in liquid smoke produced at the pyrolysis temperatures of $300^{\circ} \mathrm{C}, 320^{\circ} \mathrm{C}, 340^{\circ} \mathrm{C}, 380^{\circ} \mathrm{C}$, and $420^{\circ} \mathrm{C}$ was $10.727 \mathrm{~g} / \mathrm{L}, 17.994 \mathrm{~g} / \mathrm{L}, 17.423 \mathrm{~g} / \mathrm{L}$, and $13.269 \mathrm{~g} / \mathrm{L}$, respectively. The highest phenol content was obtained at a temperature pyrolisis of $340^{\circ} \mathrm{C}$.
\end{abstract}

Keywords: Liquid Smoke, Oil Palm Empty Fruit Bunches, Pyrolysis, Phenol, Acetic Acid

(C) RASĀYAN. All rights reserved

\section{INTRODUCTION}

Oil palm (Elaeis guineensis Jacq.) is a genus of palm widely cultivated for the production of palm oil. However, the oil palm processing industry also produces considerable waste in direct proportion to the amount of oil palm fruit processed. In oil palm mills, such by-products as fiber, empty fruit bunches, palm kernel shells, and palm kernel cake are the largest components of oil palm production that so far have less economic value than palm oil. The average production of OPEFB ranges from $22 \%$ to $24 \%$ of the total wet weight of fresh fruit bunches. ${ }^{1}$ OPEFB is widely used to produce fertilizers, ethanol, briquettes, pulp and paper, and biogas. ${ }^{2,3}$ Because of their high cellulose content, OPEFB can also be used as a raw material for liquid smoke. They can also be converted or degraded into more useful materials by a variety of biological, physical, mechanical, and thermal processes. However, the characterization of liquid smoke from OPEFB at various temperatures has not been thoroughly examined. Pyrolysis is a physical process that degrades organic materials by heating in the absence of oxidizing media. Pyrolysis is a promising technology for converting biomasses to bio-oil, char, and gas. ${ }^{4,5}$ The intensive research on biomass pyrolysis that has been conducted, ${ }^{6-8}$ tends to focus on the production of biofuel. Biofuels can be produced by pyrolysis of biomass at temperatures above $500^{\circ} \mathrm{C}$. Various types of biomass, including sawdust, ${ }^{9}$ algae, ${ }^{10}$ OPEFB,${ }^{11}$ waste tire, ${ }^{12}$, and waste potato starch, ${ }^{13}$ have recently been used to produce bio-oil through pyrolysis. Studies have also investigated pyrolysis of OPEFB at $500^{\circ} \mathrm{C} .^{14}$

Degradation of biomass can also produce other materials, mainly through pyrolysis at more moderate temperatures, for example, between $300^{\circ} \mathrm{C}$ and $450^{\circ} \mathrm{C}$. This pyrolysis produces liquid smoke that can be used for preservatives, biopesticides, and rubber coagulants. ${ }^{15-17}$ Liquid smoke from the pyrolysis of wood materials contains compounds such as phenol, carbonyl, aldehydes, ketones, acetic acid, propionate, butyrate, and valerate.

Rasayan J. Chem., 13(1), 514-520(2020)

http://dx.doi.org/10.31788/RJC.2020.1315507

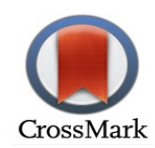




\section{RASĀYAN J. Chem. \\ Vol. 13 | No. 1 |514 - 520| January - March | 2020}

Phenol can act as an antioxidant that prolongs the durability of the material. In addition to being an antibacterial, carbonyl compounds and acids also impart flavor and color to liquid smoke. The pyrolysis of raw materials with different chemical compositions such as durian shells, palm shells, coconut shells, cocoa skin, wood waste, coconut fiber, and acacia wood produces liquid smoke with different chemical components. For example, pyrolysis of durian skin produces such components as acetic acid compounds, pyridine, butanone, dimethyl cyclopentanone, phenol, o-Methoxybenzyl alcohol, and 2-methyl-3-oxobutyronitrile ${ }^{18}$; pyrolysis of oil palm kernel shells produces different components. ${ }^{19}$ Slow pyrolysis is widely used to produce liquid smoke. So far, however, biomass pyrolysis to produce liquid smoke has been performed with little evaluation of the differing effects of different temperatures of pyrolysis. Slow pyrolysis has been used at low temperatures to produced liquid smoke with good quality. ${ }^{20}$ In certain materials, temperatures that are too high, for example, above $400^{\circ} \mathrm{C}$ will produce dangerous carcinogenic compounds. Few studies on variations in pyrolysis temperature have been conducted; one exception is a study of the pyrolysis of durian skin. ${ }^{18}$ Further investigation is needed of the effects of different ranges of temperature on the products of pyrolysis. The present study characterizes the chemical compounds produced by pyrolysis of OPEFB at $300^{\circ} \mathrm{C}$ to $420^{\circ} \mathrm{C}$. This characterization is required to ensure that the resulting liquid smoke can be used for appropriate applications, whether preservatives, biopesticides, or latex coagulants.

\section{EXPERIMENTAL}

OPEFB was pyrolyzed with a slow pyrolysis reactor, using the same procedures employed in previous studies. $^{21,22}$ The schematic diagram of the pyrolysis reactor is shown in Fig.-1. Three kg of OPEFB were put into a pyrolysis reactor made of stainless steel (Diameter: $32 \mathrm{~cm}$, Height: $50 \mathrm{~cm}$ ). The reactor was closed and heated at temperatures of $300^{\circ} \mathrm{C}, 320^{\circ} \mathrm{C}, 340^{\circ} \mathrm{C}, 380^{\circ} \mathrm{C}$, and $420^{\circ} \mathrm{C}$. The pyrolysis was done at about two hours (depending on the pyrolysis temperature). The steam was condensed to produce crude liquid smoke (which at this point was still mixed with tar). To separate liquid smoke from the remaining tar, the liquid smoke was distilled at $190^{\circ} \mathrm{C}$ until the liquid smoke was completely separated from tar ( \pm 1.5 hours). The purified composition was analyzed using GC-MS (QP2010, Shimadzu); the acetic acid and phenol were analyzed using HPLC (Hitachi L-4200H) and a spectrophotometer (Agilent Cary 60 UVVis), respectively.

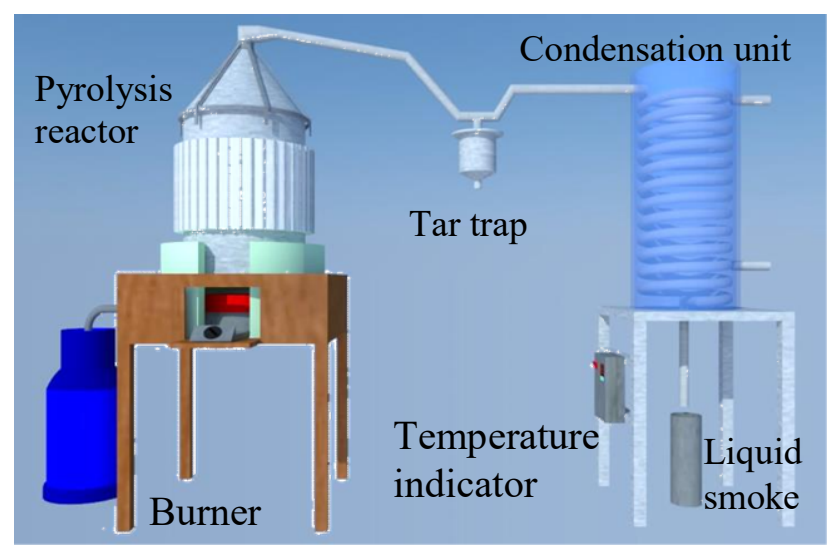

Fig.-1: Schematic Diagram of Pyrolysis Reactor

\section{Results of GC-MS Test}

\section{RESULTS AND DISCUSSION}

The decomposition of the compounds in raw materials during pyrolysis may depend on temperature. The chemical bonds are broken more rapidly on average as temperature increases. Tables 1-4 show the results of the GC-MS analysis of liquid smoke from OPEFB pyrolysis. The tables show that the products of OPEFB pyrolysis generally contain phenols, acids, esters, and ketones. The results also indicate that there were: (i) several cyclic hydrocarbon compounds such as cyclopentanone, cyclopentene, 1,3,5cycloheptatriene (CAS) cycloheptatriene, cyclopentanetridecanoic acid, and methyl ester (CAS) methyl 13-cyclopentanyltridecanoate; (ii) saturated and unsaturated linear hydrocarbons such as 3-undecene, (Z)- 
RASĀYAN J. Chem.

Vol. 13 | No. 1 |514 - 520| January - March | 2020

(CAS) cis-3-undecene, 1-pyrolysis (CAS) n-tridec-1-ene, 1-pentadecene (CAS) pentadec-1-ene, pentadecane (CAS) n-pentadecane, 1-hexadecene (CAS) cetene, and 1-nonadecene (CAS); (iii) oxygenated compounds such as hexadecenoic acid, methyl ester (CAS), methyl palmitate, hexadecenoic acid (CAS), palmitic acid, 9-octadecenoic acid, methyl ester, (E)-(CAS) methyl elaidate, and heptadecene-(8)-carbonic acid-(1). Previous studies obtained similar results, ${ }^{23}$ finding that the products of biomass pyrolysis contained hydrocarbon compounds, oxygenated compounds, and hydrocarbons. Pyrolyzed cottonseed, ${ }^{24}$ oil palm shells, ${ }^{21-25}$ durian skin biomass ${ }^{18}$, and other raw materials have also been characterized by GC-MS analysis.

Table-1: GC-MS Results of Liquid Smoke Pyrolyzed from OPEFB at $300^{\circ} \mathrm{C}$

\begin{tabular}{c|l|c}
\hline No. & \multicolumn{1}{|c}{ Senyawa } & $\%$ \\
\hline 1 & Acetic acid (CAS) Ethylic acid & 3.44 \\
\hline 2 & Acetic acid, anhydride with formic acid & 10.76 \\
\hline 3 & Pyridine (CAS) Azine & 2.74 \\
\hline 4 & Cyclopentanone (CAS) Dumasin & 1.49 \\
\hline 5 & 2-Furanmethanol (CAS) Furfuryl alcohol & 1.63 \\
\hline 6 & 2-Cyclopenten-1-one, 2-methyl- (CAS) 2-Methyl-2-cyclopentenone & 5.55 \\
\hline 7 & 2-Furanmethanol, tetrahydro- (CAS) Tetrahydrofurfuryl alcohol & 5.18 \\
\hline 8 & Benzenesulfonic acid, 4-hydroxy- (CAS) Benzenesulfonic acid, p-hydroxy- & 29.41 \\
\hline 9 & Phenol, 4-methoxy- (CAS) Hqmme & 12.62 \\
\hline 10 & Phenol, 3-methyl- (CAS) m-Cresol & 6.33 \\
\hline 11 & Azulene (CAS) Cyclopentacycloheptene & 1.45 \\
\hline 12 & 2-Methoxy-4-methylphenol & 1.65 \\
\hline 13 & Phenol, 2-ethyl- (CAS) o-Ethylphenol & 1.81 \\
\hline 14 & Phenol, 2-methoxy-3-(2-propenyl)- (CAS) Phenol, 3-allyl-2-methoxy- (CAS) 3- & 3.81 \\
\hline 15 & Trans-Caryophyllene & 4.86 \\
\hline 16 & Alpha.-Humulene & 0.58 \\
\hline
\end{tabular}

Table-2: GC-MS Results of Liquid Smoke Pyrolyzed from OPEFB at $340^{\circ} \mathrm{C}$

\begin{tabular}{c|l|c}
\hline No. & \multicolumn{1}{|c}{ Senyawa } & $\%$ \\
\hline 1 & 2-propanone (cas) acetone & 1.54 \\
\hline 2 & Acetic acid (CAS) Ethylic acid & 11.51 \\
\hline 3 & Cyclopentanone (cas) dumasin & 1.12 \\
\hline 4 & 3-methoxybuta-1,2-diene & 0.79 \\
\hline 5 & 2-Cyclopenten-1-one, 2-methyl- (CAS) 2-Methyl-2-cyclopentenone & 1.31 \\
\hline 6 & 2-Furanmethanol, tetrahydro- (CAS) Tetrahydrofurfuryl alcohol & 2.73 \\
\hline 7 & E,E-2,4-hexadienyl butanoate & 2.19 \\
\hline 8 & Benzenesulfonic acid, 4-hydroxy- (CAS) Benzenesulfonic acid, p-hydroxy- & 23.70 \\
\hline 9 & 2-Norbornanol, formate (CAS) & 20.00 \\
\hline 10 & 2,3-Dimethyl-2-cyclopenten-1-one & 6.81 \\
\hline 11 & Phenol, 2-methyl- (CAS) o-Cresol & 6.97 \\
\hline 12 & Phenol, 2-methoxy- (CAS) Guaiacol & 10.70 \\
\hline 13 & Phenol, 4-methyl- (CAS) p-Cresol & 7.99 \\
\hline 14 & 2-Methoxy-4-methylphenol & 0.80 \\
\hline 15 & Phenol, 2,6-dimethoxy- (CAS) 2,6-Dimethoxyphenol & 1.83 \\
\hline
\end{tabular}

Table-3: GC-MS Results of Liquid Smoke Pyrolyzed from OPEFB at $380^{\circ} \mathrm{C}$

\begin{tabular}{c|l|c}
\hline No. & \multicolumn{1}{|c|}{ Senyawa } & $\%$ \\
\hline 1. & 2-Propanone (CAS) Acetone & 2.63 \\
\hline 2. & Acetic acid (CAS) Ethylic acid & 2.87 \\
\hline 3. & Propenal dimethylhydrazone & 2.56 \\
\hline 4. & Ethanol, 2-(1-methylethoxy)- (CAS) 2-Isopropoxyethanol & 2.54 \\
\hline 5. & Ethanol, 2-(1-methylethoxy)- (CAS) 2-Isopropoxyethanol & 1.13 \\
\hline 6. & 2-Cyanomethyl-tetrahydrofuran & 4.19 \\
\hline
\end{tabular}


RASĀYAN J. Chem.

Vol. 13 | No. 1 |514 - 520| January - March | 2020

\begin{tabular}{c|l|c}
\hline 7. & Benzenesulfonic acid, 4-hydroxy- (CAS) Benzenesulfonic acid, p-hydroxy- & 35.53 \\
\hline 8. & 2,3-Dimethyl-2-cyclopenten-1-one & 7.47 \\
\hline 9. & Phenol, 2-methyl- (CAS) o-Cresol & 6.93 \\
\hline 10. & Phenol, 2-methoxy- (CAS) Guaiacol & 10.64 \\
\hline 11. & Phenol, 3-methyl- (CAS) m-Cresol & 8.48 \\
\hline 12. & Trans-Caryophyllene & 1.17 \\
\hline
\end{tabular}

Table-4: GC-MS Results of Liquid Smoke Pyrolyzed from OPEFB at $420^{\circ} \mathrm{C}$

\begin{tabular}{l|l|l}
\hline No. & Senyawa & $\%$ \\
\hline 1. & 2-Propanone (CAS) Acetone & 0.61 \\
\hline 2. & Acetic acid, anhydride with formic acid & 3.53 \\
\hline 3. & Acetic acid (CAS) Ethylic acid & 4.07 \\
\hline 4. & Cyclopentanone (CAS) Dumasin & 1.38 \\
\hline 5. & Acetonitrile, 2,2'-iminobis- & 0.63 \\
\hline 6. & 2-Cyclopenten-1-one, 2-methyl- (CAS) 2-Methyl-2-cyclopentenone & 1.09 \\
\hline 7. & Butanoic acid, 2-propenyl ester (CAS) allyl n-butanoate & 4.60 \\
\hline 8. & Benzenesulfonic acid, 4-hydroxy- (CAS) Benzenesulfonic acid, p-hydroxy- & 53.04 \\
\hline 9. & Phenol, 2-methyl- (CAS) o-Cresol & 6.33 \\
\hline 10. & Phenol, 2-methoxy- (CAS) Guaiacol & 8.90 \\
\hline 11. & Phenol, 4-methyl- (CAS) p-Cresol & 5.46 \\
\hline 12. & Phenol, 2-methoxy-4-(2-propenyl)- (CAS) Eugenol & 0.95 \\
\hline 13. & Trans-Caryophyllene & 0.75 \\
\hline
\end{tabular}

Because volatile compounds evaporate during distillation, compounds in liquid smoke after distillation were fewer than those in crude liquid smoke. The distillation process removed toxic compounds such as tar, benzopyrene, and hydrocarbon. At pyrolysis temperatures of $300^{\circ} \mathrm{C}, 340^{\circ} \mathrm{C}, 380^{\circ} \mathrm{C}$, and $420^{\circ} \mathrm{C}$, the samples contain $16,15,12$, and 13 compounds, respectively, consisting of phenol, acid, and carbonyl components. Liquid smoke also contains ether compounds containing alcohol, and some polyclinic and ketone compounds. Compounds such as propenal, 2-furanmethanol, tetrahydro- (CAS) tetrahydrofurfuryl alcohol, 2-cyclopenten-1-one, and 2-methyl- (CAS) 2-methyl-2-cyclopentenone are likely to result from cellulose and hemicellulose degradation. ${ }^{26}$ The main components produced by pyrolysis at $300^{\circ} \mathrm{C}, 340^{\circ} \mathrm{C}$, $380^{\circ} \mathrm{C}$, and $420^{\circ} \mathrm{C}$ were acidic compounds amounting to $29.41 \%, 23.70 \%, 35.53 \%$, and $53.04 \%$, respectively. Phenol was the second-largest component contained in liquid smoke. These results confirm a previous study by Faisal et al. ${ }^{18}$ in which durian skins were pyrolyzed into liquid smoke at the temperatures of $300^{\circ} \mathrm{C}$ to $380^{\circ} \mathrm{C}$, with acid compounds as the predominant component. Liquid smoke contains many phenolic compounds. These include phenol, 4-methoxy; phenol, 3-methyl- (CAS) mcresol; phenol, 2-methoxy-4-(2-propenyl)- (CAS) eugenol; phenol, 2-methoxy- (CAS) guaiacol; 2methoxy-4-methylphenol; and phenol, 2,6-dimethoxy- (CAS) 2,6-dimethoxyphenol. The compounds formed from cellulose decomposition have been investigated in other studies. ${ }^{27}$ Aromatic compounds contained in the pyrolysis product consist of phenols and their derivatives, benzene, xylene, pyridine, and furan derivatives. These compounds are derived from thermal degradation of lignin through the dehydration of hydroxyl groups in alkyl chains, followed by cleavage of inter-aromatic bonds of $\operatorname{lignin}^{28,29}$ and hydrolysis of ether bonds in lignin. ${ }^{30}$ Degradation of lignin compounds produces phenol compounds and methoxy groups; degradation of cellulose compounds, ketones and aldehydes, furan compounds, and hemicellulose produce acetic acid and aldehydes like furan. ${ }^{31,32}$ Oxygen-containing compounds like ketones, carboxylic acids, esters, aldehydes, and alcohols are thought to result from the decomposition of cellulose and hemicellulose through hydrolysis, dehydration, decarboxylation, and depolymerization.

\section{Acetic Acid Compositions From HPLC Test}

Acetic acid was produced by the degradation of cellulose and hemicellulose compounds that act as an antibacterial. ${ }^{33}$ The antimicrobial effects of acetic acid are influenced by concentration, $\mathrm{pH}$, environment, 
RASĀYAN J. Chem.

Vol. 13 | No. 1 |514 - 520| January - March | 2020

time, and contact temperature as well as by the species or strains of bacteria. Acidic compounds also affect product quality, including taste, aroma, and shelf life. The results of acetic acid content from OPEFB pyrolysis at various temperatures are presented in Fig.-2. The amount of acetic acid in crude liquid smoke formed from the pyrolysis of OPFB was greater than the amount that remains after distillation. Acetic acid produced in crude liquid smoke at pyrolysis temperatures of $300^{\circ} \mathrm{C}, 340^{\circ} \mathrm{C}$, $380^{\circ} \mathrm{C}$, and $420^{\circ} \mathrm{C}$ were $13.269 \mathrm{grams} / \mathrm{L}, 17.423 \mathrm{grams} / \mathrm{L}, 17.994 \mathrm{grams} / \mathrm{L}$, and $10.727 \mathrm{grams} / \mathrm{L}$, respectively. The content of acetic acid decreases after distillation to 12.376 grams $/ \mathrm{L}, 8.942 \mathrm{grams} / \mathrm{L}$, 17.811 grams/L, and 7.799 grams/L, respectively. The largest acetic acid content in crude liquid smoke and liquid smoke after distillation was produced at temperature $340 \mathrm{C}$. Acetic acid content in liquid smoke depends on cellulose content in the raw material. ${ }^{19}$ A study on liquid smoke from durian skin pyrolysis at $300^{\circ} \mathrm{C}, 340^{\circ} \mathrm{C}$, and $380^{\circ} \mathrm{C}$ showed that the content of acetic acid was $4.19 \%, 3.40 \%$, and $8.51 \%$, respectively. ${ }^{18}$ Another study showed that liquid smoke from coconut shell contains $6.72 \%$ acetic acid. $^{34}$ Acetic acid was also the predominant compound in the liquid smoke of OPEFB pyrolyzed at $380^{\circ} \mathrm{C}$.

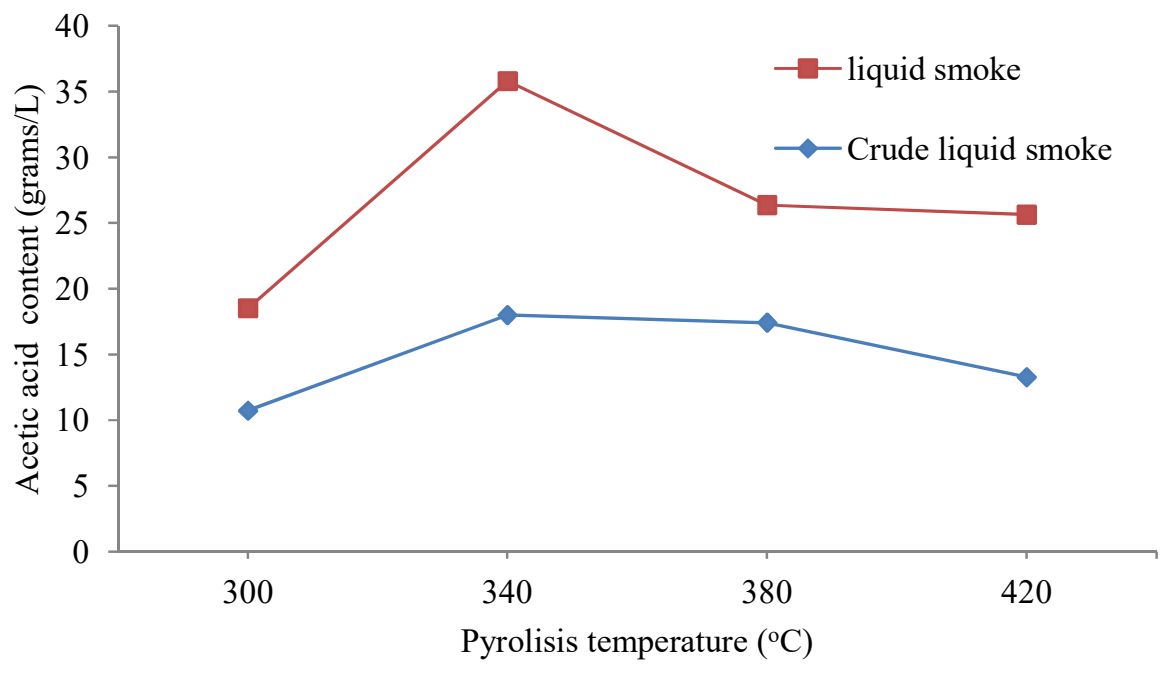

Fig.-2: Acetic Acid Content in Liquid Smoke from Pyrolyzed OPEFB

\section{Amount of Phenol Shown by Spectrophotometry Test}

Phenol compounds play an important role in developing the aromas, textures, and colors of liquid smoke products. ${ }^{33}$ Phenol compounds with a high boiling point show better antioxidant properties than those with a low boiling point. ${ }^{35}$ Phenol also works synergistically with acids and carbonyl as antimicrobials so that it can inhibit the decomposition of liquid smoke products. ${ }^{19}$ Fig.-3 shows the composition of phenol in liquid smoke from OPEFB produced by pyrolysis at various temperatures.

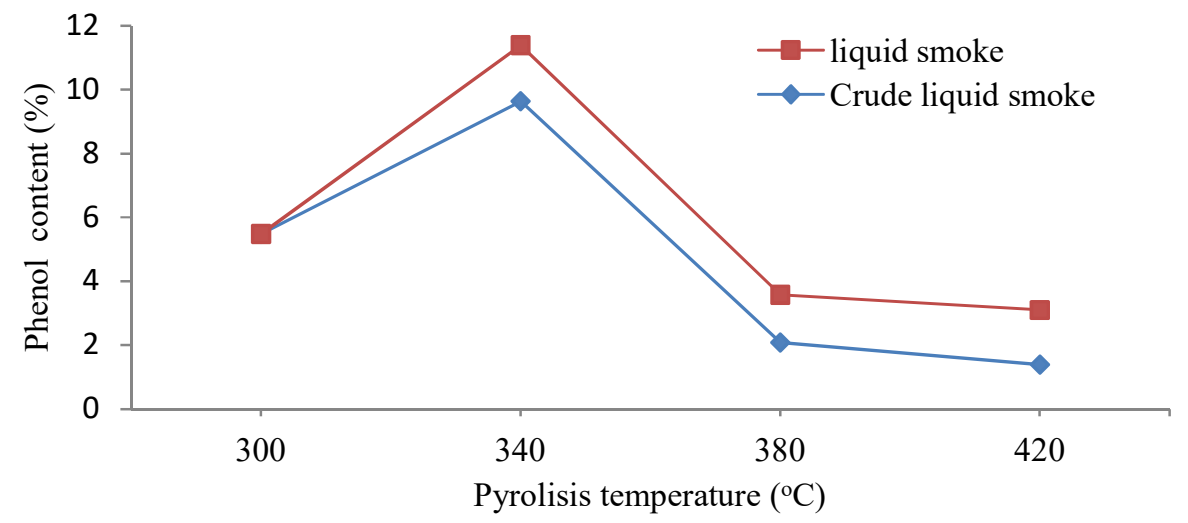

Fig.-3: Phenol Contents in OPEFB Liquid Smoke as Shown by Spectrophotometry 


\section{RASĀYAN J. Chem.}

Vol. 13 | No. 1 |514 - 520| January - March | 2020

Crude liquid smoke produced by a temperature of $340^{\circ} \mathrm{C}$ has the largest phenol content, $9.64 \%$ by wt., which after distillation decreases to $1.75 \%$ by wt. As can be seen in Fig.-3, phenol content in crude liquid smoke at $300^{\circ} \mathrm{C}, 380^{\circ} \mathrm{C}$, and $420^{\circ} \mathrm{C}$ was $5.48 \%, 2.08 \%$ and 1.39 , respectively. After distillation phenol content was $1.35 \%, 1.50 \%$ and $1.71 \%$. These phenol contents were almost similar to previous studies used durian peel waste ${ }^{18}$ and oil palm kerne ${ }^{17}$. The amount and quality of phenol depend on the temperature of pyrolysis and the amount of lignin contained in the raw material. ${ }^{33}$ The pyrolysis of oil palm shell biomass produced liquid smoke that contained fairly large aliphatic and aromatic compounds having phenol as the main component ${ }^{36}$, the maximum amount was about $8.1 \%$ by wt. $^{37}$

\section{CONCLUSION}

Differences in the temperature of OPEFB pyrolysis affect the chemical composition of liquid smoke. In the range of $300^{\circ} \mathrm{C}$ to $420^{\circ} \mathrm{C}, 12$ to 16 chemical compounds are produced, consisting of phenols, acids, esters, and ketones. The predominant compounds in OPEFB liquid smoke were the acetic acid and phenol that result from the decomposition of cellulose, hemicellulose, and lignin. In OPEFB pyrolysis at $340^{\circ} \mathrm{C}$, the amount of acetic acid in liquid smoke was 17.994 grams/L, and that of phenol was $1.75 \%$ by wt. Evaluation of the compounds in liquid smoke indicates that crude liquid smoke can be used as a rubber coagulant and that purified liquid smoke can be used as a preservative or as a natural bioinsecticide. Future research on the reaction mechanism of pyrolysis of OPEFB producing liquid smoke is required.

\section{ACKNOWLEDGMENT}

This work was funded by the Ministry of Research, Technology and Higher Education of the Republic of Indonesia under Grant Number 218/SP2H/LT/DPRM/2019. The authors wish to thank the ministry for its support.

\section{REFERENCES}

1. S. K. Loh, Energy Conversion and Management, 141, 285 (2017), DOI: 10.1016/j.enconman.2016.08.081

2. Y. L. Chiew and S. Shimada, Biomass and Bioenergy, 51, 109 (2013), DOI: 10.1016/j.biombioe.2013.01.012

3. D. C. Nieves, K. Karimi and I. S. Horváth, Industrial Crops and Products, 34, 1 (2011), DOI: 10.1016/j.indcrop.2011.03.022

4. A. V. Bridgwater, Biomass and Bioenergy, 38, 68 (2012), DOI:10.1016/j.biombioe.2011.01.048.

5. S. Hameed, A. Sharma, V. Pareek, H. Wu and Y. Yu, Biomass and Bioenergy, 123, 104(2019), DOI: 10.1016/j.biombioe.2019.02.008

6. S.Yaman, Energy Conversion and Management, 45, 5(2004), DOI:10.1016/S0196-8904(03)00177-8

7. W. N. R. W. Isahak, M. W. M. Hisham, M. A. Yarmo and T.Y. Yun, Renewable and Sustainable Energy Reviews, 16, 8 (2012), DOI: 10.1016/j.rser.2012.05.039.

8. H. Zhang, R. Xiao, D. Wang, G. He, S. Shao, J. Zhang and Z. Zhong, Bioresource Technology, 102, 5 (2011), DOI: 10.1016/j.biortech.2010.12.075

9. K. Malins, Energy Conversion and Management, 144, 243(2017), DOI: 10.1016/j.enconman.2017.04.053

10. S. R. Shanmugam and S. Adhikari, R. Shakya, Bioresource Technology, 230, 43(2017), DOI: 10.1016/j.biortech.2017.01.031

11. N. Abdullah and H. Gerhauser, Fuel, 87, 12 (2008), DOI:10.1016/j.fuel.2008.02.011

12. S. Seng-eiad and S. Jitkarnka, Journal of Analytical and Applied Pyrolysis, 122, 151(2016), DOI: 10.1016/j.jaap.2016.10.004

13. R. Posmanik, D.A Cantero, A. Malkani, D.L. Sills and J.W. Tester, The Journal of Supercritical Fluids, 119, 26 (2017), DOI:10.1016/j.supflu.2016.09.004

14. X. J. Lee, L. Y. Lee, S. Gan, S. T. Gopakumar and H. K. Ng, Biosource Technology, 236, 155 (2017), DOI: 10.1016/j.biotech.2017.03.105

15. M. Faisal, S. Utari, Z. Hayvia and I. Maulana, International Journal of GEOMATE , 17, 61 (2019), DOI:10.21660/2019.61.4679 
RASĀYAN J. Chem.

Vol. 13 | No. 1 |514 - 520| January - March | 2020

16. M. Faisal, A. Gani and F. Mulana, F1000 Research, 8, 240(2019), DOI: 10.12688/f1000research.18095.6

17. M. Faisal , A. Gani, Husni and H. Daimon, International Journal of GEOMATE, 13, 37(2017), DOI:10.21660//2017.37.2734

18. M. Faisal, A.R.Yelvia Sunarti and H. Desvita, Rasayan Journal of Chemistry, 11, 2 (2018), DOI: 10.7324/RJC.2018.1123035

19. M. Faisal, A. Gani and Husni, Rasayan Journal of Chemistry, 11, 3(2018), DOI:10.31788/RJC.2018.1132090

20. S. Maulina and F. silia, IOP Conference Series: Material Science and Engineering, 309, 12018.

21. M. Faisal, A. Gani, Husni, A. Baihaqi and H. Daimon, Journal of Engineering and Applied Sciences, 11, 12 (2016), DOI:10.3923/jeasci.2016.2583.2587

22. M. Faisal and A. Gani, International Journal of GEOMATE, 15, 47(2018), DOI: $10.21660 / 2018.47 .06109$

23. T. Kraiem, A. B. Hassen, H. Belayouni, and M. Jeguirim, Environmental Science and Pollution Research, 24, 11 (2017), DOI:10.1007/s11356-016-7704-Z

24. S. Seal, A. K. Panda, S. Kumar and R. K. Singh, Environmental Progress \& Sustainable Energy, 34, 2 (2015), DOI: 10.1002/ep.12011

25. M. Faisal, T. Chamzurni and H. Daimon, International Journal of GEOMATE, 14, 43 (2018), DOI:10.21660/2018.43.3531

26. M. D. Guillěn and M. L. Ibargoitia, Journal of Agricultural and Food Chemistry, 46, 4 (1998), DOI: 10.1021/jf970952x

27. D.K. Shen and S. Gu, Bioresource Technolog,y 100, 24 (2009), DOI:10.1016/j.biortech.2009.06.095

28. S. H. Chang, Biomass and Bioenergy, 119, 263 (2018), DOI: 10.1016/j.biombioe.2018.09.033

29. M. Misson, R. Haron, M. F. A. Kamaroddin and N. A. S. Amin, Bioresource Technology, 100, 11 (2009), DOI:10.1016/j/biortech.2008.12.060

30. S. S. Toor. L. Rosendahl and A. Rudolf, Energy, 36, 5(2011), DOI: 10.1016/j.energy.2011.03.013

31. A. Heigenmoser, F. Liebner, E. Windeisen and K. Ritcher, Journal of Analytical and Applied Pyrolysis, 100, 117(2013), DOI:10.1016/j.jaap.2012.12.005

32. A. E. Pütün, N. Özbay, E. P. Önal and E. Pütün, Fuel Processing Technology, 86, 11(2005), DOI: 10.1016/j.fuproc.2004.12.006

33. I. K. Budagara, Arnim, Y. Marlinda and U. Bulanin, International Journal of ChemTech Research, 9, $6(2016)$

34. S. Saloko, P. Darmadji, B. Setiaji, Y. Pranoto, Food Bioscience, 7, 71(2014), DOI: 10.1016/j.fbio.2014.05.008

35. A. Stolyhwo, Z. E. Sikorski, Food Chemistry, 91, 2 (2005), DOI:10.1016/j.foodchem.2004.06.012

36. A. A. Salema and F. N. Ani, Journal of Analytical and Applied Pyrolysis, 96, 162(2012), DOI: 10.1016/j.jaap.2012.03.018

37. G. Choi, S. Oh, S. Lee, and J. Kim, Bioresource Technology, 178, 99(2014), DOI: 10.1016/j.biortech.2014.08.053

[RJC-5507/2019] 